\title{
Ribosome Biogenesis Protein NOP53
}

National Cancer Institute

\section{Source}

National Cancer Institute. Ribosome Biogenesis Protein NOP53. NCI Thesaurus. Code C26433.

Ribosome biogenesis protein NOP53 (478 aa, $54 \mathrm{kDa}$ ) is encoded by the human NOP53 gene. This protein plays a role in cellular stress responses, ribosome biogenesis and the stabilization of the tumor suppressor protein PTEN. 